tis with secondary person-to-person spread in a retirement community. Am J Epidemiol 1990;131:702-710.

5. Kaplan JE, Schonberger LB, Varano G, Jackman N, Bied J, Gary GW. An outbreak of acute nonbacterial gastroenteritis in a nursing home. Am J Epidemiol 1992;116:940-948.

6. Heun EM, Vogt RL, Hudson PJ, Parren S, Gary GW. Risk factors for secondary transmission in households after a commonsource outbreak of Norwalk gastroenteritis. Am J Epidemiol 1987;126:1181-1186.

7. Chadwick PR, McCann R. Transmission of a small round-structured virus by vomiting during a hospital outbreak of gastroenteritis. J Hosp Infect 1994;26:251-259.

8. Sawyer LA, Murphy JJ, Kaplan JE, Pinsky PF, Chackow D, Walinsky S, et al. 25- to 30-nm virus particle associated with a hospital outbreak of acute gastroenteritis with evidence for airborne transmission. Am J Epidemiol 1988;127:1261-1271.

9. LeBaron CW, Furutan NP, Lew JF, Allen JR, Gouvea V, Moe C, et al. Viral agents of gastroenteritis: public health importance and outbreak management. MMWR 1990;39(RR-5):1-24.

10. Cannon RO, Poliner JR, Hirschhorn DC. A multistate outbreak of Norwalk virus gastroenteritis associated with consumption of commercial ice. J Infect Dis 1991;164:860-863.

11. Reid JA, Caul EO, White DG, Palmer SR. Role of infected food handler in hotel outbreak of Norwalk-like viral gastroenteritis: implications for control. Lancet 1988;ii:321-323.

12. Lew JF, LeBaron CW, Glass RI, Torok T, Griffin PM, Wells JG, et al. Recommendations for collection of laboratory specimens associated with outbreaks of gastroenteritis. MMWR 1990;39:1-13.

13. Ando T, Monroe SS, Gentsch JR, Jin Q, Lewis DC, Glass RI. Detection and differentiation of antigenically distinct small round-structured viruses (Norwalk viruses) by reverse transcription-PCR and Southern hybridization. J Clin Microbiol 1995;33:64-71.

14. Felsenstein J. PHYLIP: phylogeny inference package (version 3.2). PILEUP program of the Genetics Computer Group sequence analysis package. Cladistics 1989;5:164-166.

15. Devereux J, Haeberli P, Smithies O. A comprehensive set of sequence analysis programs for the VAX. Nucleic Acids Res 1984;12:387-395

\title{
HBV Vaccination of HCWs: Report Card
}

\section{Gina Pugliese, RN, MS Martin S. Favero, $\mathrm{PhD}$}

Hepatitis B virus (HBV) vaccine coverage, disease trends, and the need for booster doses after HBV vaccination of adults has been the subject of intense study during the 15 years of the vaccine's availability. The $\mathrm{CDC}$ recently published the results of a study of vaccination coverage of health care workers (HCWs) in a sample of employees from 113 randomly selected US hospitals. The number of HBV infections among HCWs and the general US population for 1983 through 1985 was estimated from national surveillance data. Studies on long-term protection after $\mathrm{HBV}$ of adults also were reviewed.

The results indicated that a total of 2,532 of 2,837 (90\%) HCWs were eli- gible to receive $\mathrm{HBV}$ vaccine, and $66.5 \%$ of them had received three doses of the vaccine.

Vaccination coverage was highest $(75 \%)$ for personnel with frequent exposure to infectious body fluids (phlebotomists, laboratory personnel, and nursing staff) and lowest (45\%) for employees at low risk for exposure (dietary and clerical). The number of HBV infections among HCWs declined from 17,000 in 1983 to 400 in 1995. The 95\% decline in incidence observed among HCWs is 1.5 -fold greater than the reduction in incidence in the general US population.

Increased vaccination coverage was higher in hospitals that provided incentives, used employee performance measures (eg, supervisor notification if an employee refused vaccination, imposed sanctions for refus- ing vaccination, required vaccination as a condition of employment, sent reminder notices when vaccine doses were due), and in hospitals that used a computerized tracking system.

A review of longitudinal studies on the long-term protection demonstrate that vaccine-induced protection persists at least 11 years, even when titers of antibody to hepatitis B surface antigen decline below detectable levels, and booster doses are not needed for individuals whose immune status is normal or who have responded to vaccination.

FROM: Mahoney FJ, Stewart K, Hanxian H, Coleman P, Alter MJ. Progress toward the elimination of hepatitis $B$ virus transmission among health care workers in the United States. Arch Intern Med 1997;157:2601-2605. 